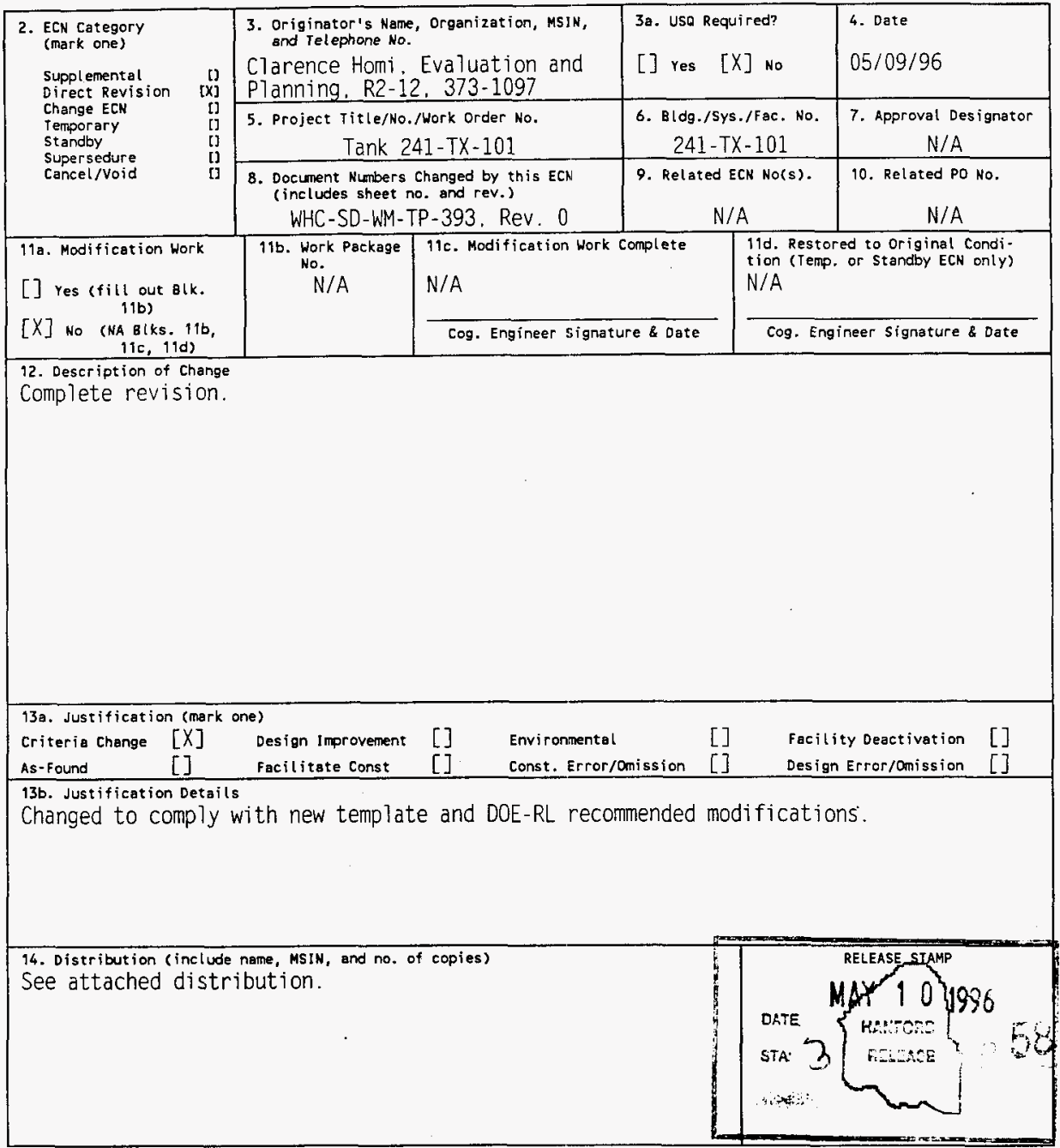




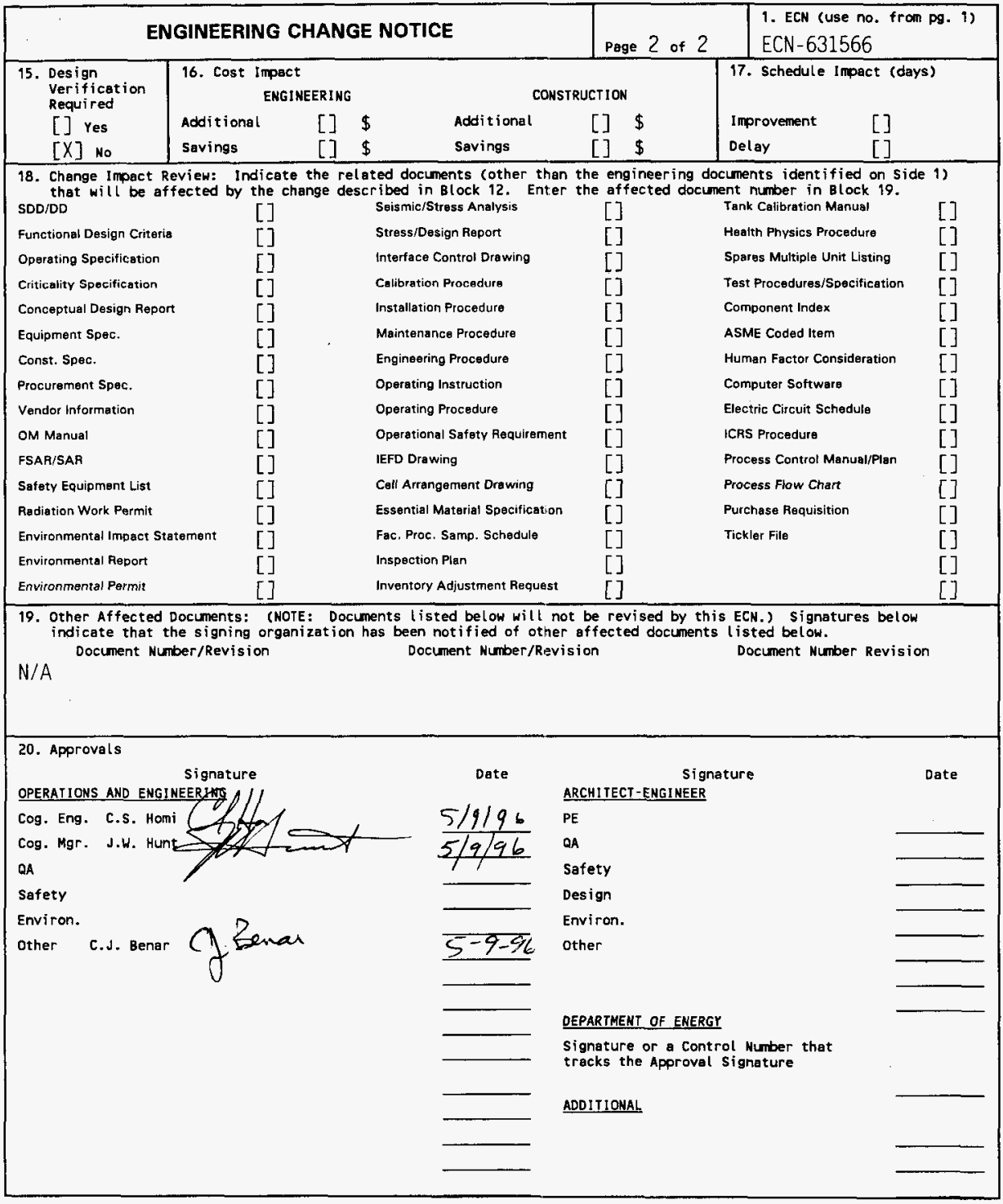


WHC-SD-WM-TP-393, Rev. 1

\section{Tank 241-TX-101 Tank Characterization Plan}

C. S. Homi

Westinghouse Hanford Company, Richland. WA 99352

U.S. Department of Energy Contract DE-AC06-87RL10930

EDT/ECN: $\quad$ ECN-631566 UC: 2070

Org Code: $79200 \quad$ Charge Code

B\&R Code: EW 3120074 Tota1 Pages: $9^{\text {N4G6A }}$

Key Words: Characterization. General Safety Issues. Specific Safety Issues, Information Requirements. Schedule

Abstract: This document is a plan that identifies the information needed to address relevant issues concerning short-term and long-term storage and long-term management of single-shell tank 241-TX-101.

TRADEMARK DISCLAIMER. Reference herein.to any specific commercial product, process, or service by trade name, trademark, manufacturer, or otherwise, does not necessarily constitute or imply its endorsement, recommendation, or favoring by the United States Goverment or any agency thereof or its contractors or subcontractors.

Printed in the United States of America. To obtain copies of this document, contact: HKC/BCS Document Control Services, P.O. Box 1970, Mailstop H6-08, Richland WA 99352, Phone (509) 372-2420; Fax (509) 376-4989.
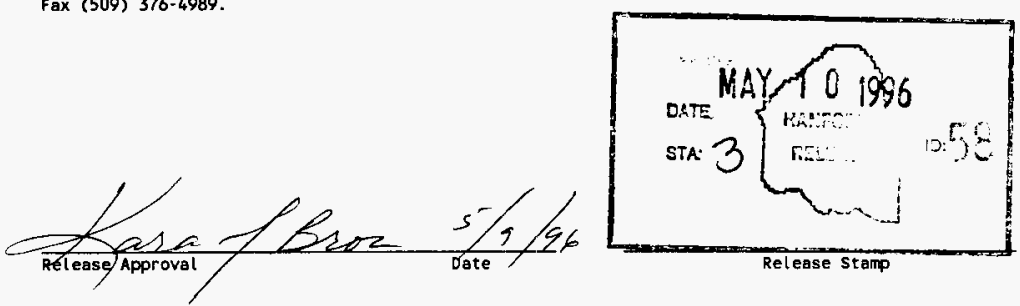

Approved for Public Release 


\section{RECORD OF REVISION}

(2) Title

Tank 241-TX-101 Tank Characterization Plan

CHANGE CONTROL RECORD

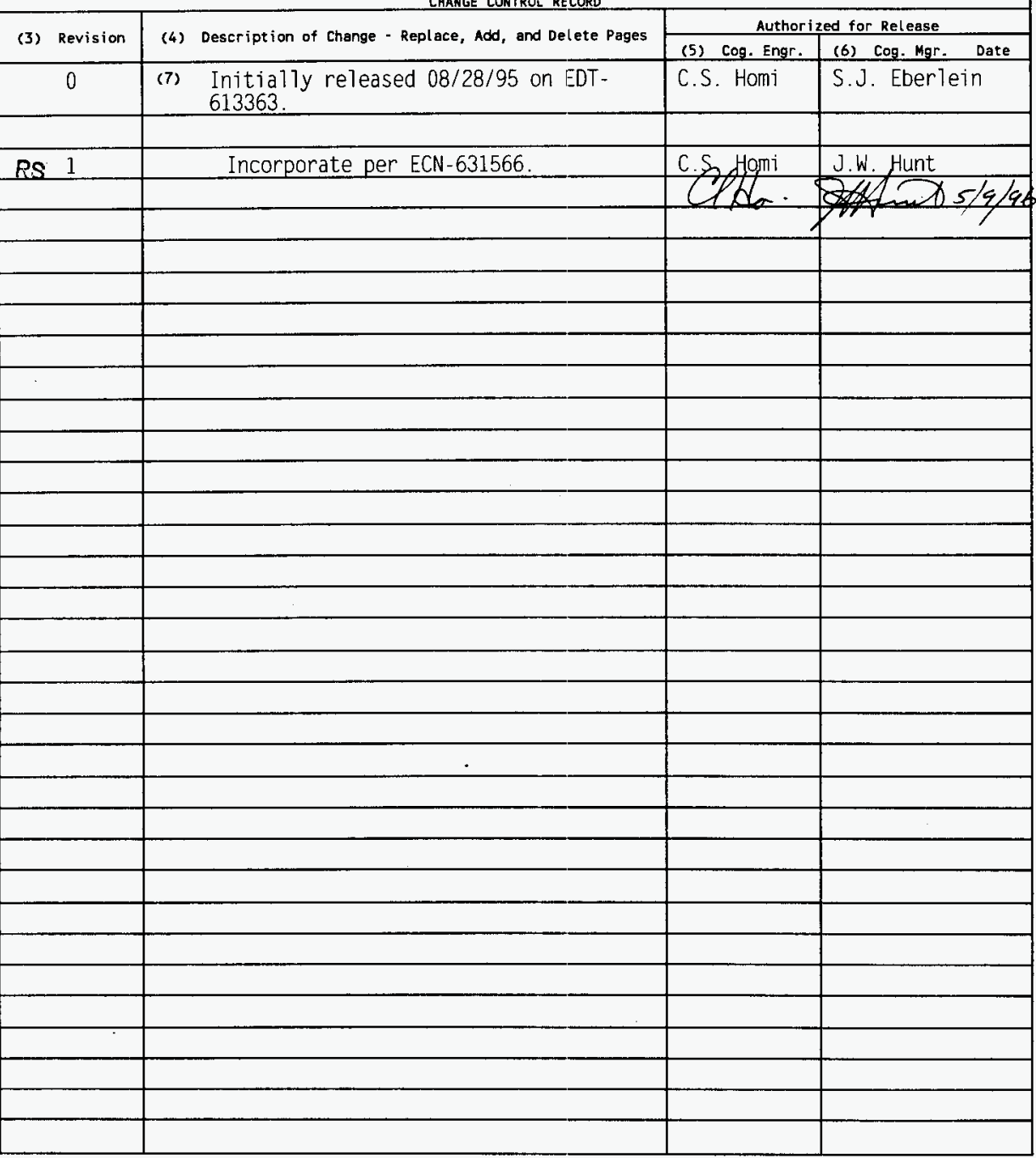


WHC-SD-WM-TP-393

Revision 1

UC-2070

\section{Tank 241-TX-101 \\ Tank Characterization Plan}

\section{J. Benar}

Westinghouse Hanford Company

Date Published

May 1996

Prepared for the U.S. Department of Energy Office of Environmental Restoration and

Waste Management

\section{(20) Westinghouse p.0. Box 1990 Hanford Company Richland, washingeron}

Management and Operations Contractor for the

U.S. Department of Energy under Contract DE-AC06-87RL 10930 
WHC-SD-WM-TP-393, Rev. 1

TABLE OF CONTENTS

1.0 INTRODUCTION . . . . . . . . . . . . . . . . . . . . . 1

2.0 PROGRAM ELEMENTS REQUIRING INFORMATION FOR TANK 241-TX-101 . . . . 2

2.1 GENERAL SAFETY ISSUES .................... 2

2.2 SPECIFIC SAFETY ISSUES ..................... . . . 2

2.2.1 Ferrocyanide . . . . . . . . . . . . . . . 2

2.2.2 Organic .................. 2

2.2 .3 High Heat ................... 2

2.2.4 Flammable Gas................. 2

2.2 .5 Vapor .................... 2

2.2.6 Criticality................ 3

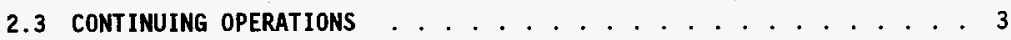

2.3.1 Compatibility/Stabilization ............. 3

2.3.2 Evaporator ................... 3

2.4 DOUble-SHELL TANK WaSte ANALYSIS PLAN . . . . . . . . . . . 3

2.5 DISPOSAL . . . . . . . . . . . . . . . . . . 3

2.5.1 Retrieval .................. 3

2.5.2 Pretreatment/Vitrification ............ 3

2.6 HISTORICAL MODEL EVALUATION .................. 3

3.0 HOW INFORMATION WILL BE OBTAINED .................. . 4

4.0 PRIORITY OF INFORMATION REQUIREMENTS . . . . . . . . . . . . . . . 4

5.0 WHEN INFORMATION WILL BE AVAILABLE ................. 4

6.0 REFERENCES ......................... 5

\section{LIST OF TABLES}

4-1 Integrated DQO Requirements and Priorities . . . . . . . . . . 4 
WHC-SD-WM-TP-393, Rev. 1

\subsection{INTRODUCTION}

This Tank Characterization Plan (TCP) identifies the information needed to address relevant issues concerning short-term and long-term safe storage and long-term management of single shell tank 241-TX-101 (TX-101). It should be understood that the various needs and issues surrounding tank TX-101 are evolving as new information about the tank is uncovered. As a result of this progression, this TCP addresses only the issues that, to this date, have been ident ified. It is expected that deviations from this plan may occur as additional issues or needs arise which impact the management of tank TX-101. As necessary, this TCP will be revised to reflect those changes or deviations. This plan reflects the best information available as of May 1996.

Tank TX-101 was constructed between 1947 and 1948 and was put into service in July 1949. Initially tank TX-101 received metal waste. During the fourth quarter of 1953, supernatant was pumped to tanks TX-106 and TX-115 in preparation of sluicing. The metal waste contained in the tank was sluiced in 1954. Tank TX-101 was sluiced again in 1955, 1956, and 1957. The tank was declared empty in the first quarter of 1957. From the second quarter of 1957 until the third quarter of 1971, TX-101 intermittently received Reduction 0xidation (RED0X) waste. Also, from the second quarter of 1971 until the second quarter of 1976 , TX-101 periodically received waste water. In the third quarter of 1976, the waste was classified as evaporator feed. In the first quarter of 1978, the waste was reclassified as non-complexed. From the third quarter of 1979 until the first quarter of 1980, the tank contained partially neutralized feed. In the second quarter of 1980, the waste was again classified as non-complexed. (Brevick et a1. 1995a). The tank is sound and was labeled inactive in 1980. Tank TX-101 is passively ventilated and was interim stabilized in February 1984 with intrusion prevention completed in August 1984. (Brevick et al. 1995b)

Tank TX-101 currently contains a volume of $329 \mathrm{~kL} \mathrm{(87} \mathrm{kgal),} \mathrm{which} \mathrm{is}$ equivalent to $99 \mathrm{~cm}(39 \mathrm{in})$ of waste as measured from the baseline of the tank.

This tank is not on any watch List.

Near-term sampling and analysis activities are focused on either verifying or changing the Watch List tank status, and identifying any new safety issues. Should any safety issues be identified, additional analysis will occur consistent with the identified issue.

In addition to the resolution of the safety issues, it is intended that all tank waste will be subject to pretreatment and retrieval to prepare for final storage or disposal. Presently, these long-range plans have yet to be fully identified and are, therefore, not included in this document. 
WHC-SD-WM-TP-393, Rev. 1

\subsection{PROGRAM ELEMENTS REQUIRING INFORMATION FOR TANK 241-TX-101}

This section identifies the various program elements, and identifies which of these programs require characterization data from tank TX-101.

\subsection{GENERAL SAFETY ISSUES}

The Tank Safety Screening Data Quality Objective (Dukelow et al. 1995) describes the sampling and analytical requirements that are used to screen waste tanks for unidentified safety issues. Analytical requirements for the safety screening of a tank are energetics, total alpha activity, moisture content, density, and flammable gas concentration.

\subsection{SPECIFIC SAFETY ISSUES}

\subsubsection{Ferrocyanide}

This tank is not on the Ferrocyanide Watch List; therefore, no information needs are currently identified for this program element.

\subsubsection{Organic}

This tank is not on the Organic Watch List; therefore, no information needs are currently identified for this program element.

\subsubsection{High Heat}

This tank is not on the High Heat Watch List; therefore, no information needs are currently identified for this program element.

\subsubsection{Flammable Gas}

This tank is not on the Flammable Gas watch List; therefore, no information needs are currently identified for this program element.

\subsubsection{Vapor}

A11 177 underground tanks must be vapor-sampled for organic solvent screening as per Recommendation 93-5 Implementation Plan (DOE-RL 1996). Some tanks may require additional vapor sampling due to other program needs. These tanks may be classified into four categories: (1) those tanks which are to be rotary mode core sampled (as a consequence of the rotary sampling system exhaust permit requirements); (2) tanks on the Organic or Ferrocyanide Watch Lists; (3) tanks in C farm; and (4) tank 241-BX-104, due to vapor exposure. Information needs must satisfy Data Quality Objectives for Tank Hazardous Vapor Safety Screening (Osborne and Buckley 1995), and for rotary mode only, Rotary Core Vapor Sampling Data Quality Objective (Price 1994), and Data Quality Objective for Regulatory Requirements for Hazardous and Radioactive Air Emissions Sampling and Analysis (Mulkey and Marki1lie 1995) as amended by Status of the Current Understanding of 
WHC-SD-WM-TP-393, ReV. 1

the Toxic Air Pollutants (TAPS) and Hanford Tank Farm Vapor Space Characterization; Recommended Path Forward and Justification for Cont inued RMCS Exhauster Operations (Laws 1996).

\subsubsection{Criticality}

No information separate from that for the general safety issue of tank TX-101 are currently identified for this program element. However, if the general safety screening of tank TX-101 identifies a potential criticality concern, analyses for fissile materials and neutron sorbers and poisons will be performed as identified in the safety screening data quality objective (DQO).

\subsection{CONTINUING OPERATIONS}

\subsubsection{Compatibility/Stabilization}

This section does not apply to tank TX-101.

\subsubsection{Evaporator}

This section does not apply to tank TX-101.

\subsection{DOUBLE-SHELL TANK WASTE ANALYSIS PLAN}

This section does not apply because tank TX-101 is a single-shell tank.

\subsection{DISPOSAL}

\subsubsection{Retrieval}

Current retrieval needs (B1oom and Nguyen 1995) do not call for test samples to be taken from tank TX-101.

\subsubsection{Pretreatment/Vitrification}

Tank TX-101 has not been identified as a bounding tank for pretreatment/ disposal process development strategy (Kupfer et a1. 1995). Al1 tanks were prioritized using the pretreatment strategy in the Tank Waste Characterization Plan and Basis (Brown et al. 1995) document and a portion of archive sample material could be used for pretreatment testing if available. The strategy does not require any specific analyses to be done on the samples.

\subsection{HISTORICAL MODEL EVALUATION}

Bounding tanks and data requirements for historical model evaluations are found in Historical Model Evaluation Data Requirements (Simpson and McCain 1995). Tank TX-101 is not identified as a primary bounding tank for historical model evaluations. 
WHC-SD-WM-TP-393, Rev. 1

\subsection{HOW INFORMATION WILL BE OBTAINED}

The number of samples required to characterize a tank is a function of waste heterogeneity and the desired confidence to make a correct decision. directed by the safety screening $D Q O$, if inadequate information exists to determine an appropriate number of samples, two vertical profiles will be obtained. These vertical profiles may be obtained using core, auger (for shallow tanks), or grab samples. If analysis of these profiles reveais that additional profiles are necessary to meet data needs, more sample profiles will be requested. Prior to rotary sampling it is necessary to vapor sample the tank per the requirements of Rotary Core Vapor Sampling Data Quality Objective (Price 1994).

\subsection{PRIORITY OF INFORMATION REQUIREMENTS}

A rotary mode sampling is scheduled to begin in June, 1997. Vapor sampling is scheduled for September, 1996 (Stanton 1996). Refer to Table 4-1 for the current $D Q 0$ requirements and planned sampling and analytical requirements.

Table 4-1: Integrated DQO Requirements and Priorities

\begin{tabular}{||l|l|l|l||}
\hline $\begin{array}{l}\text { Sampling } \\
\text { Event }\end{array}$ & \multicolumn{1}{|c|}{ Applicable Issues } & Sampling Requirements & Analytical Requirements $^{*}$ \\
\hline $\begin{array}{l}\text { Vapor } \\
\text { Sampling }\end{array}$ & $\begin{array}{l}\text {-Organic Solvent Layer } \\
\text { 93-5 Vapor Is } \\
\text {-Rotary Mode Sampling } \\
\text { DQO } \\
\text {-Hazardous Vapor DQ0 }\end{array}$ & $\begin{array}{l}\text { Steel Canisters, } \\
\text { Triple Sorbent Traps, } \\
\text { Sorbent Trap Systems }\end{array}$ & $\begin{array}{l}\text { Flammable gas } \\
\text { Organic Vapors } \\
\text { Permanent Gases }\end{array}$ \\
\hline $\begin{array}{l}\text { Rotary } \\
\text { Sampling }\end{array}$ & -Safety Screening DQ0 & $\begin{array}{l}\text { Core samples from 2 } \\
\text { risers separated } \\
\text { radially to the } \\
\text { maximum extent } \\
\text { possible } \\
\text { Combustible gas } \\
\text { measurement }\end{array}$ & $\begin{array}{l}\text { Flammability, Energetics, } \\
\text { Moisture, Total alpha } \\
\text { activity, Density }\end{array}$ \\
\hline
\end{tabular}

* Consult each applicable DQO in force at the time for analytical requirements.

\subsection{WHEN INFORMATION WILL BE AVAILABLE}

According to Stanton (1996), data are expected to be available from the rotary mode core sampling event for TX-101 in October 1997. Vapor data are expected in November 1996. These times may be altered if the sampling schedule changes. 
WHC-SD-WM-TP-393, Rev. 1

\subsection{REFERENCES}

Bloom, G. R. and Q. H. Nguyen, 1995, Characterization Data Needs for Development, Design and Operation of Retrieval Equipment Developed Through the Data Quality Objective Process, WHC-SD-WM-DQO-008, Rev. 0, West inghouse Hanford Company, Richland, Washington.

Brevick, C. H., L. A. Gaddis, and S. D. Consort, 1995a, Supporting Document for the Northwest Quadrant Historical Tank Content Estimate Report for TX Tank Farm, WHC-SD-WM-ER-321, Rev. 0, ICF Kaiser Hanford Company, Richland, Washington.

Brevick, C. H., L. A. Gaddis, and W. W. Pickett, 1995b, Historical Tank Content Estimate for the Northwest Quadrant of the Hanford 200 East Areas, WHC-SD-WM-ER-351, Rev. O, ICF Kaiser Hanford Company, Richland, Washington.

Brown, T. M., S. J. Eberlein, and T. J. Kunthara, 1995, Tank Waste Characterization P7 an and Basis, WHC-SD-WM-TA-164, Rev. 1, Westinghouse Hanford Company, Richland, Washington.

DOE-RL, 1996, Recommendation 93-5 Implementation P7an, D0E/RL-94-0001, Rev. 1, U.S. Department of Energy, Richland, Washington.

Dukelow, G. T., J. W. Hunt, H. Babad, and J. E. Meacham, 1995, Tank Safety Screening Data Quality Objective, WHC-SD-WM-SP-004, Rev. 2, Westinghouse Hanford Company, Rich7and, Washington.

Hanlon, B.M., 1996, Waste Tank Summary for Month Ending January 31, 1996, WHC-EP-0182-94, Westinghouse Hanford Company, Rich1and, Washington.

Kupfer, M. J., W. W. Schultz, and J. T. Slankas, 1995, Strategy for Sampling Hanford Site Tank Wastes for Development of Disposal Technology, WHC-SD-WM-TA-154, Rev. 1, Westinghouse Hanford Company, Richland, Washington.

Laws, G. L., 1996. Status of the Current Understanding of the Toxic Air Pollutants (TAPS) and Hanford Tank Farm Vapor Space Characterization; Recommended Path Forward and Justification for Cont inued RMCS Exhauster Operations, (telephone conference memorandum 01830-96-022, to Distribution, March 8 ), Westinghouse Hanford Company, Richland, Washington.

Mulkey, C.H., and K. D. Markillie, 1995, Data Quality Objective for Regulatory Requirements for Hazardous and Radioactive Air Emissions Sampling and Analysis, WHC-SD-WM-DQ0-021, Rev. 0, Westinghouse Hanford Company, Richland, Washington. 
Osborne, J. W., L. L. Buckley, 1995, Data Quality Objectives for Tank Hazardous Vapor Safety Screening, WHC-SD-WM-DQO-002, Rev. 2, Westinghouse Hanford Company, Richland, Washington.

Price, D. N., 1994, Rotary Core Vapor Sampling Data Quality Objective, WHC-SD-WM-SP-003, Rev. 0, Westinghouse Hanford Company, Richland, Washington.

Simpson, B. C., and D. J. McCain, 1995, Historical Model Evaluation Data Requirements, WHC-SD-WM-DQ0-018, Rev. OA, Westinghouse Hanford Company, Richland, Washington.

Stanton, G. A., 1996, Baseline Sampling Schedule, Change 96-02 (internal memo 75610-96-06 to Distribution, Apri1 17), Westinghouse Hanford Company, Richland, Washington. 


\section{DISTRIBUTION SHEET}

\begin{tabular}{|c|c|c|c|c|c|}
\hline \multirow{2}{*}{$\begin{array}{l}\text { To } \\
\text { Distribution }\end{array}$} & \multirow{2}{*}{\multicolumn{3}{|c|}{$\begin{array}{l}\text { From } \\
\text { Evaluation and Planning }\end{array}$}} & \multicolumn{2}{|l|}{ Page 1 of 1} \\
\hline & & & & \multicolumn{2}{|c|}{ Date $\quad 05 / 09 / 96$} \\
\hline \multicolumn{4}{|l|}{ Project Title $/$ Work Order } & \multicolumn{2}{|c|}{ EDT No. N/A } \\
\hline \multicolumn{4}{|c|}{$\begin{array}{l}\text { WHC-SD-WM-TP-393, Rev. 1, "Tank 241-TX-101 Tank Characterization } \\
\text { Plan" }\end{array}$} & \multicolumn{2}{|c|}{ ECN No. $\quad$ ECN-631566 } \\
\hline Nạme & MSIN & $\begin{array}{c}\text { Text } \\
\text { With } \\
\text { All } \\
\text { Attach. }\end{array}$ & Text Only & $\begin{array}{l}\text { Attach./ } \\
\text { Appendix } \\
\text { Only }\end{array}$ & $\begin{array}{l}\mathrm{EDT} / \mathrm{ECN} \\
\text { Only }\end{array}$ \\
\hline
\end{tabular}

ONSITE

U. S. Department of Energy -

Richland Field Office

W. Liou

N. W. Willis

Westinghouse Hanford Company

C. J. Benar

G. D. Forehand

C. S. Homi

Central Files

T.C.R.C. $\begin{array}{ll}\text { S7-54 } & x \\ 57-54 & x\end{array}$

$R 2-12 \quad x$

S7-21 $\quad x$

R2-12 $\quad x$

A3-88 $\quad x$

R2-12 $x$

\section{OFFSITE}

U. S. Department of Enercy - Headquarters

Office of Environmental Restoration and

Waste Management EM-563

12800 Middlebrook Road

Germantown. MD 20874

J. A. Poppiti 